\title{
Mucocutaneous complications in pediatric patients with liver transplantation
}

\author{
Karaciğer nakilli çocuk hastalarda mukokutanöz \\ komplikasyonlar \\ Fatma İssi ${ }^{1}$, Burcu Güven ${ }^{\circledR}$, Murat Çakır ${ }^{\mathbb{C}}$ \\ ${ }^{1}$ Dept. of Pediatric Gastroenterology, Karadeniz Technical University Faculty of Medicine, Trabzon, Turkey
}

\section{Abstract}

Background Liver transplant recipients can develop mucocutaneous lesions and the severity of these lesions can vary from benign to life-threatening conditions. The aim of this study was to investigate the frequency and clinical features of mucocutaneous complications after liver transplantation (LT) in pediatric patients.

Methods Retrospectively, children who underwent LT and were detected with skin and mucosa lesions while being followed up in our Pediatric Gastroenterology outpatient clinic between June 2005 and July 2020 were evaluated. Age, gender, primary diagnosis, graft type, immunosuppression history and post-transplantation mucocutaneous complications were recorded from the patients' file.

Results Mucocutaneous lesions were observed in 16 (9 girls, 7 boys) of 37 patients after LT. Mean transplantation age \pm SD was $1.96 \pm 2.03$ years and a mean follow-up period was $7.31 \pm 2.69$ years. The lesions due to viral infections were the most common dermatologic findings $(n=7,20.5 \%)$, followed by soft tissue infection $(n=6)$, xerosis $(n=5)$, urticaria $(n=3)$, eczema $(n=2)$, fissured tongue $(n=3)$, acne vulgaris $(n=3)$, tinea $(n=2)$, alopecia areata $(n=1)$, oral aphthae $(n=1)$ and leukocytoclastic vasculitis $(n=1)$. No premalignant or malignant lesion was detected in any patient.

Conclusion Studies about mucocutaneous complications are limited in children after LT and these lesions are often caused by infections associated with the side effects of immunosuppressive treatment. Accordingly, a carefully dermatological examination should be performed during the follow-up of patients undergoing LT.

Key words: liver transplantation, immunosuppressive treatment, mucocutaneous complications

\section{Özet}

Amaç Karaciğer nakil hastalarında mukokutanöz lezyonlar yüzeysel cilt lezyonlarından yaşamı tehdit eden ciddi durumlara kadar değişkenlik göstermektedir. Bu çalışmada merkezimizde takip edilen karaciğer nakilli çocuk hastalarda gözlenen mukokutanöz komplikasyonların sıklı̆̆ı ve klinik özellikleri değerlendirilmiştir.

Corresponding author: Dr. Fatma Issi , Karadeniz Technical University Faculty of Medicine, Üniversite Mahallesi, Farabi Cd. No:64, 61080 Ortahisar/Trabzon, Turkey, Phone: +90 506417 5600, E-mail: fatmaissi@gmail.com

Received: 23 December 2020 Accepted: 29 December 2020

Conflict of Interest: None.

Funding: None

How to cite this article: Issi F, Guven B, Cakir M. Mucocutaneous complications in pediatric patients with liver transplantation. Mucosa 2020;3:93-99

(c) (i) (8) This work is licensed under a Creative Commons Attribution-NonCommercial 4.0 International License. 
Yöntem Haziran 2005 - Temmuz 2020 tarihleri arasında çocuk gastroenteroloji polikliniğinde takip edilen karaciğer nakilli çocuk hastaların dosyaları retrospektif olarak incelendi. Yaş, cinsiyet, birincil tanı, greft tipi, immünosupresyon tedavisi ve transplantasyon sonrası mukokutanöz komplikasyonlar hasta dosyalarından kaydedildi.

Bulgular Karaciğer nakli sonrası mukokutanöz lezyonlar 37 hastanın 16'sında (9 kız,7 erkek) gözlendi. Ortalama nakil yaşı \pm SD $1.96 \pm 2.03$ yıl ve ortalama takip süresi $7.31 \pm 2.69$ yıldı. Dermatolojik bulgulardan en sık viral enfeksiyonlara bağlı cilt lezyonları (n=7, \%20 .5) görülürken, bunu yumuşak doku enfeksiyonu ( $n=6)$, kserozis ( $n=5)$, ürtiker ( $n=3)$, egzama $(n=2)$, dilde yarkklanma $(n=3)$, akne vulgaris $(n=3)$, tinea $(n=2)$, alopesi areata $(n=1)$, oral aft $(n=1)$ ve lökositoklastik vaskülit $(\mathrm{n}=1)$ takip etti. Premalign ve malign lezyon izlenmedi.

Sonuç Karaciğer transplantasyonu sonrası çocuklarda mukokutanöz komplikasyonlarla ilgili çalışmalar sinırlıdır ve bu lezyonlar genellikle immünosupresif tedavinin yan etkileriyle ilişkili enfeksiyonlardan kaynaklanır. Bu nedenle nakil yapılan hastaların takibinde dikkatli bir dermatolojik muayene yapılmalıdır.

Anahtar kelimeler: karaciğer nakli, immünosupresif tedavi, mukokutanöz komplikasyonlar

\section{Introduction}

Liver transplant (LT) recipients, like other solid organ transplant recipients, have an increased risk of dermatological problems due to their long-term immunosuppressive therapy. In such patients, common dermatologic findings include viral, bacterial, and fungal infections, side effects of immunosuppressive drugs (manifesting as direct skin lesions or secondary infections), precancerous lesions and malignancies. ${ }^{1}$ Acne vulgaris, cushingoid appearance, xerosis and gingival hyperplasia are frequently seen as side effects of immunosuppressive treatment. Additionally, atopic dermatitis and eczema can also be seen, though rarely. ${ }^{2}$

Compared to other solid organ transplants, LT requires less immunosuppressive treatment and may even allow complete cessation of drugs in some cases. Therefore, LT often have fewer dermatological compli- cations compared to other solid organ transplant recipients. ${ }^{3}$ In such patients, a careful dermatological examination should be performed during the follow-up period since the severity of skin lesions can vary from benign to life-threatening conditions. In this study, we aimed to investigate the frequency and clinical features of mucocutaneous complications after LT in pediatric patients followed up in our outpatient clinic.

\section{Methods}

Since 2005, 37 children have been followed up underwent LT in our pediatric gastroenterology outpatient clinic. Sixteen (43.2\%) of these patients were observed with dermatologic complications. Clinical data including age, gender, primary diagnosis, graft type, immunosuppression history and post-transplantation mucocutaneous complications were recorded from the patients' file.

In statistical analysis, descriptives were expressed as mean \pm standard deviation (SD) for continuous variables and as percentages (\%) for categorical variables. Ethics committee approval was not obtained because of the retrospective nature of the study.

\section{Results}

Demographic and clinical findings of the patients who underwent LT were presented in table 1 . The main indications for LT were cholestatic liver diseases $(n=26,70.3 \%)$ including biliary atresia $(n=12$, $32.4 \%$ ), progressive familial intrahepatic cholestasis $(n=8)$, congenital hepatic fibrosis $(n=2)$, Alagille syndrome $(n=2)$, Caroli disease $(n=1)$ and Crigler-Najjar syndrome $(n=1)$. Five $(13.5 \%)$ patients underwent LT for metabolic liver diseases, including Tyrosinemia type $1(n=3)$ and Wilson's disease $(n=2)$. Five (13.5\%) patients were transplanted due to acute liver failure (paracetamol and ethanol intoxications, infantile liver failure syndrome, hepatitis A, indeterminate etiology). Autoimmune hepatitis was seen in one $(2.7 \%)$ patient. Thirty-four (91.9\%) patients were transplanted from a living donor, 3 (8.1\%) recipients obtained from cadaveric donors. Immunosuppressive therapy was given with tacrolimus in $32(86.5 \%)$ and sirolimus with 5 
Table 1. Demographic and clinical characteristics of patients with underwent LT

\begin{tabular}{|c|c|}
\hline Parameters & n (\%) \\
\hline \multicolumn{2}{|l|}{ Age at time of LT } \\
\hline Mean $\pm S D$, years & $3.43 \pm 3.69$ \\
\hline Median, years & 1.6 \\
\hline \multicolumn{2}{|l|}{ Gender } \\
\hline Female & $21(56.7)$ \\
\hline Male & $16(43.3)$ \\
\hline \multicolumn{2}{|l|}{ Primary diagnosis } \\
\hline Cholestatic LD & $26(70.3)$ \\
\hline Metabolic LD & $5(13.5)$ \\
\hline Autoimmune hepatitis & $1(2.7)$ \\
\hline Acute liver failure & $5(13.5)$ \\
\hline \multicolumn{2}{|l|}{ Graft type } \\
\hline Living donor & $34(91.9)$ \\
\hline Cadaveric donor & $3(8.1)$ \\
\hline \multicolumn{2}{|l|}{ Immunosuppression } \\
\hline Tacrolimus & $32(86.5)$ \\
\hline Sirolimus & $5(13.5)$ \\
\hline \multicolumn{2}{|l|}{ Duration of follow up } \\
\hline Mean $\pm S D$, years & $6.70 \pm 3.66$ \\
\hline Median, years & 6.7 \\
\hline $\begin{array}{l}\text { Mucocutaneous } \\
\text { complications }\end{array}$ & $16(43.2)$ \\
\hline
\end{tabular}

LT, liver transplantation; LD, liver disease; SD, standard deviation

(13.5\%) patients.

Thirty-four mucocutaneous complications were developed in 16 (9 girls, 7 boys) patients after liver transplantation. Mean transplantation age \pm SD was $1.96 \pm$ 2.03 years (median 0.9 year). Mean time from transplantation to the onset of skin lesions was $7.31 \pm 2.69$ years (median 6.9 years). Patients' with mucocutaneous complications after LT demographic and clinical characteristics are presented in table 2 . The mucocutaneous complications mostly occurred secondary to infections ( $n=15,44.1 \%)$. Seven $(20.5 \%)$ of them had a viral, six (17.7\%) had bacterial and two (5.9\%) had fungal origin. The other dermatologic findings included $\operatorname{xerosis}(n=5)$, urticaria $(n=3)$, eczema $(n=2)$, fissured tongue $(n=3)$, acne vulgaris $(n=3)$, alopecia areata $(n=1)$, oral aphthae $(n=1)$ and leukocytoclastic vasculitis $(n=1)$. No premalignant or malignant lesion was observed in any patient. There were not any immunosuppressive drug changes due to dermatologic complication.

Dermatologic lesions associated with viral pathogens were including Herpes simplex virus $(n=2)$, hand-foot and mouth disease $(n=2)$, Varicella zoster virus (VZV) $(\mathrm{n}=1)$ and Human Papillomavirus (HPV) $(\mathrm{n}=1)$. Herpes simplex virus (HSV) was seen two patients; one of them had perioral vesicles after three years from LT and was treated by topical antiviral cream. The other patient had perioral and genital vesicles after 1.5 years from LT and was treated by intravenous (iv) acyclovir. Two patients had hand-foot and mouth disease, and they were given symptomatic treatment. Four years after the transplant, diffuse vesicles were seen on the trunk due to VZV in one patient and iv acyclovir treatment was given. HPV was seen as warts on the palate in one patient.

Bacterial soft tissue infections were detected in six (17.7\%) patients. Four of them were seen at the surgical area. Staphylococcus epidermidis and Staphylococcus aureus were observed in swab cultures in two patients. Surgical area infections were treated with oral/iv antibiotics. Periorbital cellulitis was seen in one patient and were given netilmicin eye drop for treatment (Fig. 1a). Additionally, one patient had soft tissue infection on the left breast after itching due to dermatitis (Fig. 1b). The lesion resolved with topical antibiotic therapy. Tinea cruris and corporis were seen in two (5.9\%) patients as superficial fungal infections. Tinea cruris treated with sertaconazole cream. Tinea corporis was seen on the lateral side of the right hip and was treated with naftifine cream for two weeks (Fig. 1c). Both lesions regressed with topical treatment.

Dermatologic complications associated with immunosuppressive regimen included; xerosis $(n=5)$, acne vulgaris $(n=3)$, fissured tongue $(n=3)$, alopecia areata 
Table 2. Demographic and clinical characteristics of patients with mucocutaneous complications after LT

\begin{tabular}{|c|c|c|c|c|c|c|c|c|}
\hline Patient & Gender & $\begin{array}{l}\text { Age at } \\
\text { LT } \\
\text { (years) }\end{array}$ & $\begin{array}{l}\text { Primary } \\
\text { disease }\end{array}$ & $\begin{array}{l}\text { Type of } \\
\text { LT }\end{array}$ & $\begin{array}{l}\text { Immuno } \\
\text { suppres- } \\
\text { sion }\end{array}$ & $\begin{array}{l}\text { LT to } \\
\text { lesions } \\
\text { (years) }\end{array}$ & Diagnosis or findings & Treatment \\
\hline$\# 1$ & $\mathrm{~F}$ & 0.8 & $\begin{array}{l}\text { Crigler-Najjar } \\
\text { syndrome }\end{array}$ & $\begin{array}{l}\text { Living } \\
\text { donor }\end{array}$ & Tacrolimus & 7 & Xerosis & Moisturizer \\
\hline$\# 2$ & $\mathrm{~F}$ & 0.4 & Biliary atresia & $\begin{array}{l}\text { Living } \\
\text { donor }\end{array}$ & Tacrolimus & $\begin{array}{l}3 \\
8\end{array}$ & $\begin{array}{l}\text { Perioral vesicle } \\
\text { Tinea corporis }\end{array}$ & $\begin{array}{l}\text { Topical antiviral } \\
\text { Naftifine cream }\end{array}$ \\
\hline$\# 3$ & M & 3.5 & Biliary atresia & $\begin{array}{l}\text { Living } \\
\text { donor }\end{array}$ & Tacrolimus & $\begin{array}{l}1 \\
3\end{array}$ & $\begin{array}{l}\text { Xerosis } \\
\text { Hand-foot-and-mouth }\end{array}$ & $\begin{array}{l}\text { Moisturizer } \\
\text { Antipyretic }\end{array}$ \\
\hline$\# 4$ & $\mathrm{~F}$ & 0.6 & $\begin{array}{l}\text { Congenital he- } \\
\text { patic fibrosis }\end{array}$ & $\begin{array}{l}\text { Living } \\
\text { donor }\end{array}$ & Tacrolimus & $\begin{array}{l}5 \\
8 \\
9 \\
13 \\
13.5\end{array}$ & $\begin{array}{l}\text { Urticaria-angioedema } \\
\text { Fissured tongue } \\
\text { Warts } \\
\text { Acne vulgaris } \\
\text { Soft tissue infection }\end{array}$ & $\begin{array}{l}\text { Adrenaline } \\
\text { Oral zinc } \\
\text { Adapalene cream } \\
\text { Fucidic acid }\end{array}$ \\
\hline$\# 5$ & $\mathbf{M}$ & 1 & Biliary atresia & $\begin{array}{l}\text { Living } \\
\text { donor }\end{array}$ & Tacrolimus & 4 & Hand-foot-and-mouth & Antipyretic \\
\hline$\# 6$ & $\mathrm{~F}$ & 0.4 & Biliary atresia & $\begin{array}{l}\text { Living } \\
\text { donor }\end{array}$ & Tacrolimus & $\begin{array}{l}1.5 \\
2.5 \\
3 \\
4 \\
5\end{array}$ & $\begin{array}{l}\text { Perioral-genital vesicles } \\
\text { Acne vulgaris } \\
\text { Eczema } \\
\text { Hand-foot-and-mouth } \\
\text { Alopecia areata }\end{array}$ & $\begin{array}{l}\text { IV acyclovir } \\
\text { Moisturizer }\end{array}$ \\
\hline$\# 7$ & $\mathbf{M}$ & 0.4 & PFIC -1 & $\begin{array}{l}\text { Living } \\
\text { donor }\end{array}$ & Tacrolimus & 4.5 & Xerosis & Moisturizer \\
\hline$\# 8$ & $\mathrm{~F}$ & 5 & PFIC-1 & $\begin{array}{l}\text { Living } \\
\text { donor }\end{array}$ & Tacrolimus & 3.5 & Leukocytoclastic vasculitis & NSAID \\
\hline$\# 9$ & $\mathbf{M}$ & 0.8 & PFIC-2 & $\begin{array}{l}\text { Living } \\
\text { donor }\end{array}$ & Tacrolimus & $\begin{array}{l}0.4 \\
1.5 \\
2 \\
3 \\
3.5\end{array}$ & $\begin{array}{l}\text { Tinea cruris } \\
\text { Fissured tongue } \\
\text { Oral aphthae } \\
\text { Urticaria } \\
\text { Acne vulgaris }\end{array}$ & Fucidic acid \\
\hline$\# 10$ & $\mathrm{~F}$ & 1.5 & Tyrosinemia & $\begin{array}{l}\text { Living } \\
\text { donor }\end{array}$ & Tacrolimus & $\begin{array}{l}0.7 \\
0.8\end{array}$ & $\begin{array}{l}\text { Xerosis } \\
\text { Soft tissue infection }\end{array}$ & Oral antibiotic \\
\hline$\# 11$ & M & 2.5 & Tyrosinemia & $\begin{array}{l}\text { Cadaveric } \\
\text { donor }\end{array}$ & Tacrolimus & 1.5 & Soft tissue infection & Fucidic acid \\
\hline$\# 12$ & $\mathbf{M}$ & 0.3 & $\begin{array}{l}\text { Congenital he- } \\
\text { patic fibrosis }\end{array}$ & $\begin{array}{l}\text { Living } \\
\text { donor }\end{array}$ & Sirolimus & $\begin{array}{l}0.1 \\
3\end{array}$ & $\begin{array}{l}\text { Soft tissue infection } \\
\text { Soft tissue infection }\end{array}$ & $\begin{array}{l}\text { IV Teicoplanin } \\
\text { Oral antibiotic }\end{array}$ \\
\hline$\# 13$ & $\mathrm{~F}$ & 6 & Biliary atresia & $\begin{array}{l}\text { Living } \\
\text { donor }\end{array}$ & Tacrolimus & 6.5 & Urticaria & Desloratadine \\
\hline$\# 14$ & $\mathrm{~F}$ & 6 & Biliary atresia & $\begin{array}{l}\text { Living } \\
\text { donor }\end{array}$ & Tacrolimus & 8 & Eczema & Moisturizer \\
\hline \#15 & $\mathrm{F}$ & 1.5 & Tyrosinemia & $\begin{array}{l}\text { Living } \\
\text { donor }\end{array}$ & Tacrolimus & $\begin{array}{l}3 \\
4\end{array}$ & $\begin{array}{l}\text { Xerosis } \\
\text { Vesicle }\end{array}$ & IV acyclovir \\
\hline$\# 16$ & $\mathbf{M}$ & 0.8 & Biliary atresia & $\begin{array}{l}\text { Living } \\
\text { donor }\end{array}$ & Sirolimus & 9 & Soft tissue infection & $\begin{array}{l}\text { Netilmicin eye } \\
\text { drop }\end{array}$ \\
\hline
\end{tabular}

LT, liver transplantation; IV,intravenous; NSAID, nonsteroidal anti-inflammatory drug; PFIC, progressive familial intrahepatic cholestasis 
$(n=1)$ and oral aphthae $(n=1)$. A patient with fissured tongue is shown in figure $1 \mathrm{~d}$. All of them were given topical treatment or vitamin supplement. Leukocytoclastic vasculitis was observed as a rare complication considered secondary to immunosuppressive therapy in only one patient. Non-steroidal anti-inflammatory therapy was given as treatment. No immunosuppres-

\section{Discussion}

There are limited studies about dermatologic complications after solid organ transplantation in children. ${ }^{1}$ In LT patients, as in other solid organ transplant recipients, dermatologic findings can result from primary side effects of immunosuppressive drugs or can occur secondary to infections. Moreover, serious dermato-

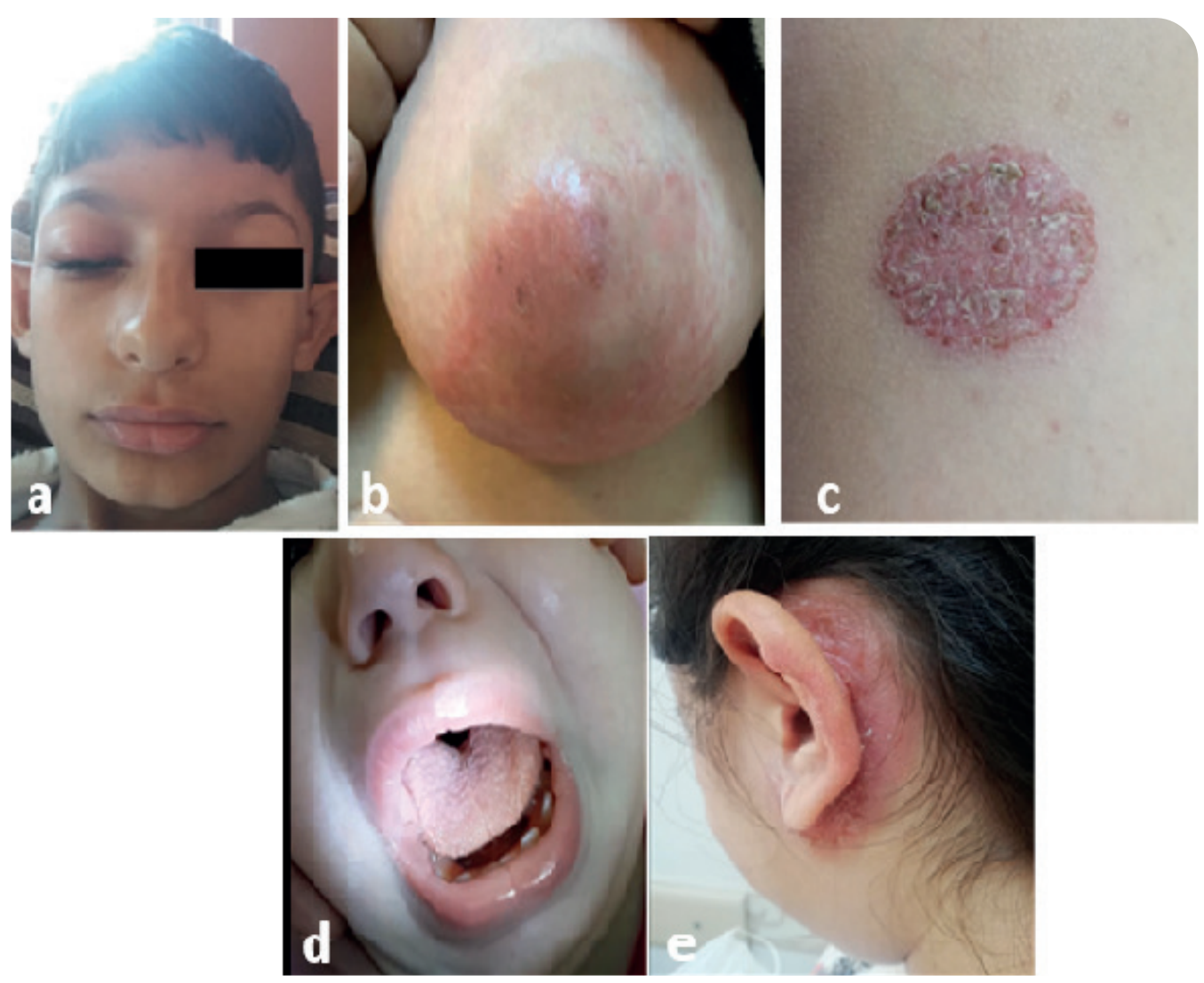

Fig. 1a. Skin infection on the right palpebra (case 16), 1b. Skin infection after dermatitis on the left breast around the areola (case 4), 1c. Tinea corporis on the lateral side of the right hip (case 2), 1d. Fissured tongue (case 9), 1e. Eczema behind the left ear (case 14)

sive therapy change was needed in any patient.

Three $(8.8 \%)$ patients had urticaria and one of them was accepted as angioedema after admission due to swelling of the lips. Hazelnut allergy was detected in the skin prick test. One of the other two patients had a negative skin prick test. Two (5.9\%) patients had eczema and were treated with moisturizing cream. The patient with an eczematous lesion behind the left ear is shown in figure le. logical complications such as skin cancer may develop due to the immune-mediated effects of the transplanted organ and long-term immunosuppressive therapy. ${ }^{2,3}$ Dermatological infections caused by viruses, bacteria and fungi may be observed after $\mathrm{LT}^{4}{ }^{4}$ While bacterial and viral infections are frequently seen in the early period after transplantation, rare bacterial and opportunistic infections are detected in the late peri- 
od. Herpes viruses are the most common viral causes. Dermatological symptoms associated with HSV are usually atypical and manifest as necrosis, painless ulcer, and pseudotumoral mass. The infection rate due to HSV may be up to $35 \%$ and HSV reactivation is usually seen within the first three weeks after transplantation. Cytomegalovirus (CMV), though rarely seen, is among the most important infections after liver transplantation and often occurs during initial strong immunosuppressive therapy. ${ }^{5}$ Most common dermatologic findings after LT include polymorphous vesicles, ulceration, necrotic lesions in oral cavity, and genital lesions. Other viral agents include Herpes zoster, Epstein-Barr virus, Parvovirus B19, HPV and HHV-6 and HHV-7. ${ }^{6}$ In our study, skin lesions associated with viral pathogens were observed in seven patients (21.2\%); including HSV ( $n=2)$, hand-foot and mouth disease $(n=2)$, Varicella zoster $(n=1)$ and HPV $(n=1)$. In the literature, there are studies reporting enteroviruses as a cause of hand-foot-mouth disease. ${ }^{7}$

Among all bacterial infections, surgical area infection due to Staphylococcus aureus is the most common infection, accounting for approximately $10 \%$ of bacterial wound site infections. The other common infections are caused by Escherichia coli and Pseudomonas aeruginosa..$^{5-7}$ In our study, bacterial soft tissue infection was observed in six (17.7\%) patients.

Regarding fungal infections, Tinea versicolor is seen in $10-20 \%$ of LT patients, usually on the face and hip. In this infection, the lesions can be large and occasionally hyperkeratotic as well. ${ }^{8,9}$ Dicle et al. reported the prevalence of dermatophytosis in their patients as $11.7 \%$ and also noted that tinea corporis was detected in $4.2 \%$ and tinea cruris in $2 \%$ of the patients. ${ }^{10}$ In our study, superficial fungal infections were seen in two $(5.9 \%)$ patients; tinea cruris and tinea corporis in one patient each.

Immunosuppressive drugs used after transplantation have been associated with mucocutaneous complications such as acne vulgaris, cushingoid appearance, xerosis and gingival hyperplasia. Common dermatologic side effects of tacrolimus include gingival hyper- plasia, petechiae secondary to immune thrombocytopenia, acne vulgaris. Alopecia, cellulite, condyloma accuminatum, dermal ulcer, dermatitis, hyperhidrosis, hypotrichosis, pityriasis versicolor, pruritus and skin discoloration may also be seen. ${ }^{11}$ Sirolimus has been shown to cause peripheral edema, rash, delayed wound healing, acneiform eruption, increased risk of skin cancers, hair loss or hypertrichosis, dermatitis and mucositis/oral ulcer. ${ }^{12}$ In our study, dermatologic complications associated with immunosuppressive treatment included xerosis $(n=5)$, acne vulgaris $(n=3)$, fissured tongue $(n=3)$, alopecia areata $(n=1)$ and oral aphthae $(n=1)$. All patients detected with these findings were receiving tacrolimus. Immunosuppressive regimen did not have to be changed due to any of these complications.

Atopic dermatitis or eczema is a common chronic inflammatory skin disease characterized by dry skin and recurrent episodes of itchy eruptions. Cases of new onset or those with worsening of pre-existing atopic dermatitis after transplantation have been reported. Children are affected more often than adults and the average time from transplant to onset of atopic eczema is first 12 months. ${ }^{13}$ Tacrolimus has been shown to increase intestinal permeability and to cause food allergens to pass the intestinal barrier more easily. Additionally, it has also been suggested that tacrolimus may cause an increase in cytokines such as interleukin-4, 5, 13 and T-helper 2, which are the main mediators of atopic diseases. ${ }^{13,14}$ In our study, two patients were detected with eczematous lesions. Urticaria was observed in three patients and one of them had angioedema secondary to hazelnut allergy.

Although leukocytoclastic vasculitis has been commonly reported in LT patients using sirolimus, Sharma et al. reported five out of seven patients with vasculitis were using tacrolimus. ${ }^{15}$ In our study, leukocytoclastic vasculitis was detected in only one patient using tacrolimus. Despite the lack of documentation regarding the mechanism between tacrolimus and vasculitis, infections occurring in patients using immunosuppressive drugs are considered to trigger vasculitis. ${ }^{11}$ 
Studies evaluating the time from transplantation to the onset of dermatological lesions have shown that bacterial and viral infections are frequently seen in the early post-transplant period. Serious complications such as opportunistic or rare bacterial infections and skin cancer secondary to immunosuppressive treatments may develop in the late period. ${ }^{16}$ Dermatologic lesions in our study were frequently observed $>1$ year after transplantation and the longest follow-up period was 13.5 years. Although no premalignant or malignant lesion was observed in our patients, these lesions should be kept in mind during the long-term follow-up period.

\section{Conclusion}

Mucocutanous complications after LT in children often result from infectious conditions occurring secondary to immunosuppressive therapy. In these patients, serious complications such as skin cancer should be kept in mind and a carefully dermatological examination should be performed during the follow-up period.

\section{References}

1. Imko-Walczuk B, Roskosz-Stozkowska M, Szymanska K, Kadylak D, Debska-Slizien A. Skin cancer in children after organ transplantation. Postepy Dermatol Alergol 2019;36:649-54.

2. Yadav DK, Bai XL, Liang T. Dermatological disorders following liver transplantation: An update. Can J Gastroenterol Hepatol 2019;2019:9780952.

3. Ertam I, Alper S, Unal I. et al. Karaciğer transplant hastalarında deri bulgularının transplantasyon süresi ile ilişkisi. Turk J Dermatol 2013;7:72-5.

4. Ilyas M, Maganty N, Ginsberg Z, Sharma A. Skin infections due to bacteria in solid organ transplant recipients: a review. Dermatology 2017;233:358-65.

5. Naldi L, Venturuzzo A, Invernizzi P. Dermatological complications after solid organ transplantation. Clin Rev Allergy Immunol 2018;54:185-212.

6. Hernandez M del P, Martin P, Simkins J. Infectious complications after liver transplantation. Gastroenterol Hepatol (N Y) 2015;11:741-53.

7. Kim JE, Oh SH, Kim KM, et al. Infections after living donor liver transplantation in children. J Korean Med Sci 2010;25:527-31.

8. Schmied E, Dufour JF, Euvrard S. Nontumoral der- matologic problems after liver transplantation. Liver Transpl 2004;10:331-9.

9. Ilyas M, Sharma A. Cutaneous fungal infections in solid organ transplant recipients. Transplant Rev (Orlando) 2017;31:158-65.

10. Dicle O, Parmaksizoglu B, Gurkan A, Tuncer M, Demirbas A, Yilmaz E. Skin infections in 401 renal transplant recipients in southern Turkey. Exp Clin Transplant 2009;7:133-6.

11. Yang JW, Liao SS, Zhu LQ, et al. Population pharmacokinetic analysis of tacrolimus early after Chinese pediatric liver transplantation. Int J Clin Pharmacol Ther 2015;53:75-83.

12. Dumortier J, Couchonnal E, Lacaille F, et al. mTOR inhibitors in pediatric liver transplant recipients. Clin Res Hepatol Gastroenterol 2019;43:403-9.

13. Almaas R, Haflidadottir S, Kaldestad RH, Matthews IL. Asthma, eczema, and food allergy in children following liver transplantation. J Pediatr 2019;204:263-9.

14. Topal E, Catal F, Selimoglu MA, et al. Acquired atopic disease after liver transplantation in children; similarities to and differences from adults: a preliminary study. Eur J Gastroenterol Hepatol 2014;26:1055-9.

15. Ilyas M, Sharma A. Leukocytoclastic vasculitis in transplant recipients: A case series of 7 patients. JAAD Case Rep 2017;3:291-3.

16. Hassan G, Khalaf H, Mourad W. Dermatologic complications after liver transplantation: a single-center experience. Transplant Proc 2007;39:1190-4. 